\title{
Faktor-Faktor Yang Mempengaruhi Efisiensi Perbankan Suatu Studi Pada Bank Swasta Yang Terdaftar Di Bursa Efek Indonesia
}

\author{
LIVIAWATI $^{1}$; JENI WARDI ${ }^{2}$; GUSMARILA EKA PUTRI ${ }^{3}$ \\ Universitas Lancang Kuning Pekanbaru \\ Jln. Yos Sudarso KM 08 Rumbai Telp. (0761) 52581 \\ E-mail : gusmarillaekaputri@unilak.ac.id
}

\begin{abstract}
Banks that have good management if the bank can show good performance in this case are reflected by how much the bank's ability to make efficiency in its operations. Efficiency is a capability or ability of banks to obtain bank profits or profits with minimal costs. In the first quarter of 2016 several banks such as Bank Mandiri experienced a decline in profit, followed by BTPN, Artha Graha and others. The decline in bank profits was caused by these banks operating inefficiently. In the last few semesters researchers have conducted research on the factors that affect the profitability of banks where researchers have conducted research in private banks, BPRs, and SOEs where the results of the study indicate that the decline in profitability was caused by inefficient banks. the value of efficiency is measured by the ratio of financial efficiency, namely BOPO. The purpose of this study is to examine the effect of capital on bank efficiency, to test the effect of liquidity on bank efficiency, to examine the effect of net interest margins on bank efficiency, to examine the effect of risk on bank efficiency and to examine the effect of ownership on bank efficiency. The results of this study found that there are 3 factors that partially affect the efficiency of private banks, namely company size, CAR, and NPL, while LDR, NIM, and market interest rates do not affect the efficiency of private banks. And these 6 factors simultaneously affect the efficiency of private banks, this can be seen by the magnitude of the influence of these 6 factors that is equal to $83.7 \%$
\end{abstract}

Keywords: Efficiency, Private Banks, Liquidity, NIM

Bank merupakan suatu lembaga yang menghimpun dana sebesar-besarnya dari masyarakat. Semakin besar bank dapat menghimpun dana dari masyarakat, akan semakin besar kemungkinan bank tersebut dapat memberikan kredit dan ini berarti semakin besar kemungkinan bank tersebut memperoleh pendapatan (interest income), sebaliknya semakin kecil dana yang dapat dihimpun semakin kecil pula kredit yang diberikan, maka semakin kecil pula pendapatan bank. Operasional bank sangat unik jika dibandingkan dengan perusahaanperusahaan lainnya, bank dalam beroperasi tidak semata-mata mengandalkan modal akan tetapi mengandalkan kemampuan perusahaan dalam menghimpun dana dari masyarakat yang kelebihan dana.

Daya saing perbankan dapat tercermin dari tingkat efisiensi operasional. Namun, besarnya tingkat efisiensi ini akan sangat bergantung pada berbagai faktor, baik yang bersifat mikro maupun makro. Faktor - faktor tersebut diantara adalah suku bunga pasar, pertumbuhan ekonomi, volatilitas pasar, tingkat harga tenaga kerja, biaya energi dan faktor-faktor lainnya. Diantar faktor-faktor penentu efisiensi tersebut, tingkat suku bunga dana dipasar merupakan salah satu faktor yang sangat menentukan tingkat efisiensi operasional bank karena besarnya cost of fund bank. Selain itu tingkat persaingan supply kredit yang menentukan pola pembentukan pasar kredit juga berpengaruh terhadap efisiensi operasional perbankan. Dalam suatu pasar yang mengalami supply rigidity, supply kredit akan cenderung didominasi oleh beberapa bank, sehingga lembaga perbankan akan dapat memaksimalkan keuntungan jangka pendek. Namun, secara jangka panjang bank - bank tersebut akan kehilangan daya 
kompetitifnya untuk bersaing secara efisien. Dampak lebih luasnya adalah masyarakat selaku pengguna dana akan mengalami kesulitan untuk mendapatkan sumber dana yang murah untuk menjalankan usahanya dan pada akhirnya juga akan menetukan daya saing industri dalam negeri.

Dalam rangka mencermati hal tersebut, diperlukan suatu rumusan kebijakan makroprudensial yang dapat menjembatani tujuan-tujuan mikro, yaitu antara lain tercapainya kinerja keuangan bank umum di Indonesia secara baik dan pada saat yang sama juga memberikan iklim yang kondusif terhadap pertumbuhan ekonomi nasional, walaupun pada hakikatnya kualitas asset suatu sistem perbankan akan sangat bergantung pada kualitas pembangunan sistem perekonomian suatu negara secara jangka panjang.

Pada semester 1 tahun 2016 PT Bank permata TBK melaporkan kinerja yang buruk dengan mengalami kerugian sebesar Rp 835,67 miliar atau Rp 65 per saham bila dibandingkan kinerja pada semester 1 tahun 2015 lalu yang membukukan laba bersih sebesar 837,31 miliar atau Rp 70 per saham. Penurunan kinerja bank permata tersebut disebabkan oleh cadangan kerugian penurunan nilai aset keuangan perseroan yang melonjak dari Rp 845,60 miliar menjadi Rp 2,94 triliun atau melonjak $247,43 \%$ dan beban operasional perseroan juga mengalami peningkatan dari $\mathrm{Rp} 2,19$ triliun menjadi Rp 2,32 triliun sedangkan beban bunga dan syariah menurun dari $\mathrm{Rp} 5,21$ triliun menjadi $\mathrm{Rp}$ 4,50 trilun. Selain peningkatan dari beban kerugian penurunan dari aset keuangan, pendapatan bunga dan syariah perseroan juga mengalami penurunan dari Rp 8,19 triliun menjadi Rp 7,44 triliun, sedangkan pendapatan operasional perseroan meningkat dari Rp 1,14 triliun menjadi 1,22 triliun.Rasio NPLgross dan net masing-masing naik menjadi $3,5 \%$ dan $1,8 \%$ per 31 maret 2016 , dari $1,6 \%$ ditahun sebelumnya. Total aset hingga 31 maret
2016 mengalami penurunan sebesar 8\% menjadi Rp 175 triliun, terutama didorong oleh penurunan kredit sebesar $6 \%$ menjadi Rp 123 triliun.

Bank Mandiri, salah satu BUMN perbankan terbesar di Indonesia mengalami hal yang sama. Laba bank mandiri mengalami penurunan sebanyak $25,7 \%$ mencatatkan laba bersih sebesar Rp 3,817 miliar di kuartal 1 tahun 2016. Selain itu penurunan laba bersih juga nampaknya imbasnya dari meningkatnya biaya pencadangan kredit perseroan ( provisi ) sebesar 198,61\% menjadi Rp 4,31 triliun. Hal ini juga diiringi naiknya rasio kredit bermasalah atau non perfoming loan ( NPL ) gross dari 1,81\% menjadi $2,89 \%$.

PT bank mega TBK mencatat kinerja relatif flat di semester 1 tahun 2016. Laba bersih bank berkode emiten mega ini mengalami penurunan $2,71 \%$ menjadi 539 miliar. Penurunan tipis laba bersih disebabkan beban operasional selain bunga bersih yang naik cukup tinggi yaitu $69,24 \%$.Kenaikan beban operasional ini lebih tinggi dari kenaikan pendapatan bunga bersih yang tumbuh $35,71 \%$. Untuk likuiditas, tercatat bank mega akan menjaga likuiditas dengan menetapkan posisi LDR pada kisaran $65 \%$ sampai $70 \%$.

PT bank tabungan pensiunan nasional TBK ( BTPN ) melaporkan laba bersihnya menurun $6,9 \%$ menjadi 1,75 triliun pada akhir tahun lalu dibandingkan tahun sebelumnya sebesar 1,88 triliun. Pertumbuhan pendapatan bunga tahun lalu melampaui pertumbuhan beban bunga. Pendapatan bunga perseroan meningkat $5,7 \%$ menjadi 13 triliun. Sementara, beban bunga hanya naik kurang dari $1 \%$ menjadi 5,3 triliun. Beban operasional perseroan naik $13,7 \%$ yaitu dari 2,61 triliun pada akhir 2014 menjadi sebesar 2,97 triliun pada akhir tahun lalu. Sedangkan pendapatan operasionalnya hanya tumbuh $1,8 \%$ menjadi sebesar 235,02 triliun. Di sisi lain cadangan kerugian penurunan nilai meningkat. PT 
bank artha graha internasional TBK masih lemah pada tiga bulan pertama tahun 2016 ini. Hal ini terlihat dari laba bersih bank berkode emiten INPC ini yang turun $33,33 \%$ menjadi 32,28 miliar, Penurunan laba ini disebabkan kenaikan biaya operasional yang lebih tinggi dibandingkan dengan pendapatan bersih. Pada kuartal 1 tahun 2016, bank milik taipan tomy winata ini mencatatkan kenaikan biaya operasional sebesar 20,63\% sedangkan pendapatan bunga bersih hanya tumbuh tipis $7,97 \%$. Direktur utama bank artha graha, andi kasih mengatakan, penurunan laba salah satunya disesbabkan karena pertumbuhan bisnis secara umum masih lambat, kendala terutama dari sektor riil yang menyebabkan cash flow masih berat. Selain kenaikan biaya operasional, penurunan laba juga akibat turunnya penyaluran kredit. Tercatat pada kuartal 1 tahun 2016, penyaluran kredit turun 2,44\% menjadi 17,01 triliun. Sedangkan dana pihak ketiga hanya tumbuh tipis $0,17 \%$ menjadi 21,02 triliun. Pada kuartal pertama tahun 2016 rasio kredit bermasalah ( NPL ) bank artha graha turun 44,34 menjadi $2,41 \%$. Untuk rasio beban operasional ( BOPO ) dan net interst margin pada akhir maret 2016 tercatat masih di level 93,3\% dan $5 \%$.

Berdasarkan latar belakang yang diutarakan diatas maka peneliti merumuskan rumusan masalah penelitian sbb :

1. Apakah Ukuran perusahan berpengaruh terhadap efisiensi bank swasta

2. Apakah loan to deposit rasio (LDR) berpengaruh terhadap efisiensi bank swasta

3. Apakah net performing loan (NPL) berpengaruh terhadap efisiensi bank swasta

4. Apakah modal (CAR) berpengaruh terhadap efisiensi bank swasta

5. Apakah Net Interest Margin (NIM) berpengaruh terhadap efisiensi bank swasta
6. Apakah suku bunga pasar berpengaruh terhadap efisiensi bank swasta

7. Apakah ukuran perusahaan, LDR NPL,CAR,NIM, suku bunga pasar, kepemilikan dan tipe bank berpengaruh terhadap efisiensi bank swasta

Bank adalah lembaga yang berperan sebagai perantara keuangan (financial intermediary) antara pihak yang memiliki dana dan pihak yang memerlukan dana, serta sebagai lembaga yang berfungsi memperlancar lalu lintas pembayaran ( PSAK No.31).

Rasio-rasio keuangan:

1. Rasio Likuiditas

Rasio ini mengukur kemampuan bank untuk memenuhi kewajiban finansial jangka pendeknya atau kewajiban yang telah jatuh tempo. Rasio likuiditas diukur dengan menggunakan rasio Loan Deposit Ratio (LDR), yaitu rasio antara jumlah seluruh kredit yang diberikan bank dengan dana yang diterima oleh bank. Menurut Dendawijaya ( 2005:80)

$$
\text { Loan to Deposit Ratio }=\frac{\text { Kredit }}{\text { Dana pihak ketiga }}
$$

2. Modal ( Capital adequacy ratio / CAR )

Capital Adequacy Ratio (CAR), yaitu rasio untuk mengukur kecukupan modal yang dimiliki bank untuk menunjang aktiva yang mengandung atau menghasilkan resiko.Semakin besar nilai CAR mencerminkan kemampuan perbankan yang semakin baik dalam menghadapi kemungkinan resiko kerugian. Perhitungan CAR dengan rumus CAR $=\frac{\text { Modal }}{\text { ATMR }} \quad$ x $\quad 100 \%$

\section{Resiko}

Dalam pemberian kredit, bank akan menghadapi resiko yang salah satunya adalah kredit macet, oleh karena 
itu kredit-kredit, yang tidak lancar tersebut diperlukan adanya kebijakan dan prosedut penyelamatan yang mendasar, tepat dan efektif. Bank Indonesia melalui peraturan Bank Indonesia menetapkan bahwa rasio kredit bermasalah ( NPL ) adalah sebesar 5 $\%$ dengan perhitungan :

$$
\mathrm{NPL}=\frac{\text { Kredit Bermasalah }}{\text { Total Kredit }} \times 100 \%
$$

Net interest margin adalah ukuran perbedaan antara bunga pendapatan yang dihasilkan oleh bank atau lembaga keuangan lain dengan nilai bunga yang dibayarkan kepada pemberi pinjaman mereka ( misalnya deposito ) relatif terhadap jumlah mereka ( bunga produktif ). Rasio net interest margin adalah rasio yang digunakan untuk menganalisis seberapa besar pendapatan bunga bersih dibandingkan dengan aset produktif.

Rumus NIM :

NIM $=\frac{\text { Pendapatan bunga }}{\text { Aktiva produktif }}$

\section{Pengukuran Efisiensi}

Pengukuran efisiensi selain menggunakan DEA dapat juga diukur dengan rasio keuangan yaitu beban operasional terhadap pendapatan opersional ( BOPO ). Pengukuran efisiensi dengan menggunakan rasio keuangan diatas disebut pengukuran efisiensi keuangan. Adapun rumus untuk mengukur efisiensi keuangan :

$$
\mathrm{BOPO}=\quad \text { Beban operasional }
$$

Pendapatan operasional

Hipotesis penelitian ini adalah :

H1 : Ukuran perusahan berpengaruh terhadap efisiensi bank swasta

H2 : Loan to deposit rasio ( LDR ) berpengaruh terhadap efisiensi bank swasta
H3 : Net performing loan ( NPL ) berpengaruh terhadap efisiensi bank swasta

H4 : Modal ( CAR ) berpengaruh terhadap efisiensi bank swasta

H5 : Net Interest Margin berpengaruh terhadap efisiensi bank swsta

H6 : Suku bunga pasar berpengaruh terhadap efisiensi bank swasta

H7 : Ukuran perusahaan, LDR NPL,CAR,NIM, suku bunga pasar, kepemilikan dan tipe bank swasta berpengaruh terhadap efisiensi bank pemerintah

\section{METODE}

Objek penelitian dalam penelitian ini adalah laporan keuangan bank swasta yang terdaftar dibursa efek indonesia di Indonesia.

Populasi yang digunakan dalam penelitian ini adalah bank swasta yang terdaftar dibursa efek Indonesia .

Sampel penelitian ada bank swasta yang memenuhi kriteria sbb :

1. bank swasta yang termasuk kedalam bank rangking 20 besar menurut OJK

2. bank swasta yang memiliki data lengkap yang dibutuhkan dalam penelitian ini

3. bukan Bank swasta milik asing

4. bukan bank hasil merger atau penggabungan usaha

Data yang digunakan pada penelitian, tehnik pengambilan sampelnya menggunakan tehnik purposive sampling dg kriteria :

1. bank swasta yang termasuk kedalam bank rangking 20 besar menurut OJK

2. bank swasta yang memiliki data lengkap yang dibutuhkan dalam penelitian ini

3. bukan Bank swasta milik asing

4. bukan bank hasil merger atau penggabungan usaha

Jenis data yang digunakan dalam penelitian ini adalah data kuantitatif yaitu data yang diambil dari laporan keuangan 
dan data-data publikasi seperti data tingkat suku bunga pasar.

Sumber data yang digunakan adalah sekunder yaitu data yang diperoleh melalui penelusuran dari media internet website www.idx.co.id dan data yang dipublikasikan bank indonesia

1. Penelitian pustaka yang dilakukan dengan cara mengumpulkan literatur yang ada hubungannya dengan penelitian dengan tujuan untuk mendapatkan landasan teori dan teknik analisa data dalam memecahkan masalah.

2. Pengumpulan data laporan keuangan Bank Umum yang telah dipublikasikan

Untuk menganalisis data penelitian ini digunakan analisa regresi berganda.

persamaan regresi yang di gunakan adalah sebagai berikut:

$$
\begin{aligned}
& \mathrm{Y}=\mathrm{B}+\mathrm{B}_{1} \mathrm{x}_{1}+\mathrm{B}_{2} \mathrm{x}_{2}+\mathrm{B}_{3} \mathrm{x}_{3}+\mathrm{B}_{4} \mathrm{x}_{4}+\mathrm{B}_{5} \mathrm{x}_{5}+ \\
& \ldots \ldots+\mathrm{e} .
\end{aligned}
$$

Keterangan :

$$
\begin{array}{ll}
\mathrm{Y} & =\text { Efisiensi keuangan }(\mathrm{BOPO}) \\
\mathrm{B} & =\text { Konstanta } \\
\mathrm{B}_{1}-\mathrm{B}_{8} & =\text { Koefisien regresi } \\
\mathrm{X}_{1} & =\text { ukuran perusahaan } \\
\mathrm{X}_{2}=\text { modal ( CAR ) } & \\
\mathrm{X}_{3}=\text { Likuiditas ( LDR ) } \\
\mathrm{X}_{4}=\text { Resiko ( NPL ) } \\
\mathrm{X}_{5}=\text { Net Interest margin } \\
\mathrm{X}_{6}=\text { Suku bunga pasar } \\
\mathrm{E} & =\text { error }
\end{array}
$$

\section{HASIL}

Pada penelitian ini terdapat 9 bank swasta yang dijadikan sampel yaitu Bank Danamon, Bank Panin, CIMB Niaga, OCBC NISP, Bank Mega, Bank Permata, BCA, Bank BTPN.

Berdasarkan deskriptif data di atas dapat dijelaskan bahwa rata-rata BOPO pada sembilan bank yang dijadikan sampel diatas, besaran rata-rata BOPO nya adalah 80.64, angka ini masih angka dibawah batasan BOPO yang ditetapkan oleh bank indonesia yaitu $85 \%$. Sedangkan rata-rata CAR bank yang dijadikan sampel adalah 18,30 dimana angka rata-rata ini menunjukkan bahwa kesembilan bank yang dijadikan sampel telah memiliki CAR diatas dari ketentuan bank Indonesia dimana bank Indonesia menentukan bahwa minimum CAR bank adalah sebesar $12 \%$.

Hasil pengujian data secara parsial ditunjukkan pada tabel 5.2 dibawah ini dengan ketentuan bahwa jika nilai sig < dari 0.05 maka $\mathrm{H}_{1}$ diterima dan $\mathrm{H}_{0}$ ditolak akan tetapi jika nilai sig > 0.05 maka $\mathrm{H}_{1}$ ditolak dan $\mathrm{H}_{0}$ diterima.

Berdasarkan hasil uji $t$ terlihat bahwa ada 3 variabel yang mempengaruhi efisiensi bank pemerintah yaitu CAR.NPL dan ukuran perusahaan. Untuk melihat apakah semua variabel berpengaruh secara bersama-sama terhadap efisiensi bank pemerintah, maka hasil uji $\mathrm{F}$ yang menggambar berpengaruh atau tidaknya variabel yang diteliti secara bersama sama. Berpengaruh atau tidaknya variabel secara bersama-sama jika tingkat sig uji $\mathrm{F}<0.05$. Berdasarkan tabel uji $\mathrm{F}$ dapat kita simpulkan bahwa pengaruh variabel CAR, LDR, NPL, ukuran perusahaan, n NIM dan tingkat suku bunga terhadap efisiensi bank swasta adalah sebesar $83,7 \%$ sedangkan $16,3 \%$ dipengaruhi oleh variabel lain yang tidak diteliti pada penelitian ini.

\section{PEMBAHASAN}

\section{Pengaruh ukuran perusahaan terhadap efisiensi bank swasta}

Pada penelitian ini ukuran perusahaan diukur dengan menggunakan total aset. Berdasarkan hasil uji t pada tabel 5.2 di atas terlihat bahwa ukuran perusahaan berpengaruh terhadap efisiensi bank swasta. Semakin besar perusahaan diperlukan alat pengawasan dan kontrol yang lebih komplek sehingga jika perusahaan tidak menyikapinya dengan penggunaan tehnologi maka bisa menyebabkan biaya operasional yang besar apalagi perusahaan yang hanya mengandalkan alat kontrol yang secara manual akan lebih besar lagi biaya yang 
akan dikeluarkan maka akan semakin tidak efisienlah operasional perusahaan tersebut.

Perusahaan perbankan merupakan perusahaan yang melakukan pelayanan ke segenap lapisan masyarakat. Semakin besar perbankan itu maka semakin komplek juga alat pengawasan dan kontrol yang harus dilakukan oleh perbankan. Pengawasan yang komplek dan luas akan efisien jika kita menggunakan tehnologi. Akan tetapi penggunaan tehnologi membutuhkan biaya yang besar pula. Hal ini tentu akan berhubungan dengan modal perbankan itu sendiri.

\section{Pengaruh Loan deposit rasio ( LDR ) terhadap efisiensi bank swasta}

LDR merupakan indikator untuk mengukur kemampuan bank dalam memenuhi hutang jangka pendek yang jatuh tempo. Berdasarkan tabel 5.2 diatas terlihat bahwa LDR tidak berpengaruh terhadap efisiensi bank swasta

\section{Pengaruh NPL terhadap efisiensi bank swsta}

Berdasarkan tabel 5.2 diatas terlihat bahwa NPL berpengaruh terhadap efisiensi bank swasta. NPL merupakan indikator untuk mengetahui keadaan kualitas aktiva produktif yaitu kualitas kredit perbankan. Semakin tinggi NPL berarti kredit perbankan itu banyak macet. Kredit macet akan mengakibatkan pendapatan bunga yang berasal dari kredit tersebut tidak dapat diterima bank dan juga biaya operasional juga akan meningkat terutama dalam hal untuk melakukan penagihan serta biayabiaya lainnya.

\section{Pengaruh CAR terhadap efisiensi bank swasta}

CAR merupakan indikator untuk melihat permodalan bank. Berdasarkan tabel 5.2 diatas terlihat bahwa CAR berpengaruh terhadap efisiensi bank swasta. Seperti yang sudah dijelaskan diatas bahwa semakin besar suatu bank maka semakin kompleks pengawasan dan kontrol yang diperlukan. Pengawasan dan kontrol yang efisien membutuhkan inovasi tehnologi agar pengawasan dan kontrol yang kompleks ini bisa dilaksanakan dengan biaya yang efisiens. Penggunaan tehnologi membutuhkan modal yang besar untuk membangunnya.

\section{Pengaruh NIM terhadap efisiensi bank swasta}

NIM merupakan rasio yang digunakan untuk mengukur kemampuan bank dalam menghasilkan pendapatan terutama dari bunga kredit yang diberikan kepada nasabah. Berdasarkan tabel 5.2 terbukti bahwa NIM tidak berpengaruh terhadap efisiensi bank swasta.

\section{Pengaruh Suku bunga pasar terhadap efisiensi bank swasta}

Berdasarkan tabel 5.2 terlihat bahwa tingkat suku bunga tidak berpengaruh terhadap efisiensi bank swasta. Tingkat suku bunga yang dipakai pada penelitian ini adalah tingkat suku bunga pasar.

\section{SIMPULAN}

Berdasarkan hasil penelitian di atas maka peneliti menyimpulkan :

1. Berdasarkan hasil uji t bahwa ada 3 faktor secara parsial yang mempengaruhi efisiensi bank swasta yaitu factor ukuran perusahaan, CAR, dan NPL, sedangkan LDR, NIM, dan tingkat suku bunga pasar tidak berpengaruh terhadap efisiensi bank swasta.

2. Berdasarkan hasil uji simultan bahwa 6 faktor (ukuran perusahaan, LDR, NPL, CAR, NIM, suku bunga) berpengaruh terhadap efisiensi bank swasta, hal ini terlihat dengan besarnya pengaruh 6 faktor tersebut yaitu sebesar $83,7 \%$.

Ada beberapa saran kepada beberapa pihak yang peneliti usulkan diantara :

1. Bagi bank swasta, dengan diketahuinya hasil penelitian yang telah diuraikan di atas, untuk bisa lebih memperhatikan dan 
meningkatkan

kemampuan

permodalan untuk mengoptimalkan penggunaan teknologi yang akan meningkatkan efisiensi. Kemudian yang perlu dikontrol adalah tingkat pinjaman nasabah yang macet. Mungkin perlu program yang dapat dilakukan untuk mengurangi tingkat NPL di bank.

2. Bagi peneliti selanjutnya, diharapkan dapat menambah variabel lain yang mempengaruhi efisiensi suatu bank swasta selain variabel yang sudah diujikan dalam penelitian ini.

\section{DAFTAR RUJUKAN}

Taswan, 2010. Manajemen Perbankan ; konsep teknik dan Aplikasi Edisi 2, UPP STIM, Yogyakarta

Kasmir, 2011, Manajemen Perbankan. PT. Raja Grafindo Persada, Jakarta.

Dendawijaya, 2005, Manajemen Perbankan, Ghalia Indonesia, Jakarta

Kasmir, 2008, Bank dan Lembaga Keuangan Lain, PT. Raja Grafindo Persada, Jakarta

Kasmir, 2008, Analisis Laporan Keuangan, PT. Raja Grafindo Persada, Jakarta

Ikatan Akuntansi, 2010, Pernyataan Standar Akuntansi Keuangan No.31 Akuntansi Perbankan, Salemba Empat, Jakarta.

Abdullah, M. Faisal, 2005. Manajemen Perbankan, Edisi Kelima, Universitas Muhammadiyah Malang, Malang.

Riyadi, 2006. Manajemen Perbankan, Cetakan Pertama, Bumi Aksara, Jakarta

Darmawi, H., 2011.Manajemen Perbankan. Jakarta: Bumi Aksara
Perwitaningtias,dkk 2015, faktor-faktor yang mempengaruhi efisiensi bank di Indonesia periode 2008-2012, diponegoro jurnal of management, vol 4. No 1, http://ejournals1.undip.ac.id/index.php/dbr

Havrychk,Olena 2006, Efficiency of polish Banking industry: foreign versus domestic banks. Journal of banking and finance. http://www.ssrn.com

Muazaroh, dkk, 2012 determinants of bank profit efficiency: evidance from indonesia international journal of economics and finance studies, vol 4 , No 2

Subandi,ghozali imam 2012, determinasi efisiensi dan dampaknya terhadap kinerja profitabilitas industri perbankan di Indonesia, Jurnal jurnal keuangan dan perbankan, Vol 17 No. 1 Des 2012 https://www.researchgate.net/ http://jurkubank.wordpress.com. Diakses 31 Oktober 2018

Girardone,C.,P dkk,2004, Analysing the determinants of bank efficiency : the case of italian banks. Applied Economics. http://dx.doi.org 